\title{
Creativity, Culture and Translation
}

\author{
Siamak Babaee ${ }^{1}$, Wan Roselezam Wan Yahya ${ }^{2} \&$ Ruzbeh Babaee ${ }^{2}$ \\ ${ }^{1}$ Faculty of Foreign Languages, University of Kashan, Iran \\ ${ }^{2}$ Faculty of Modern Languages and Communication, University Putra Malaysia, Malaysia \\ Correspondence: Ruzbeh Babaee, Faculty of Modern Languages and Communication, University Putra Malaysia, \\ Malaysia. E-mail: rbabaei30@yahoo.ca
}

Received: March 3, 2014 Accepted: April 4, 2014 Online Published: May 14, 2014

doi:10.5539/elt.v7n6p14 URL: http://dx.doi.org/10.5539/elt.v7n6p14

\begin{abstract}
Some scholars (Bassnett-McGuire, Catford, Brislin) suggest that a good piece of translation should be a strict reflection of the style of the original text while some others (Gui, Newmark, Wilss) consider the original text untranslatable unless it is reproduced. Opposing views by different critics suggest that translation is still a challenging issue. The present study examines the relationship between translation and culture. The purpose of this study is to consider translation as a creative act based on cultural differences in both source language (SL) and target language (TL). We suggest that culture is a factor that can bestow creativity to translation. Thus, a great deal of cultural communication between two languages should be considered for translating any text.
\end{abstract}

Keywords: creative translation, culture, source language, target language

\section{Introduction}

It has been acknowledged that every act of reading is a kind of interpretation and decoding of the text. In fact, translation is a process of decoding the meaning of the source text (ST). Therefore, every translation is an expansion of the ST in the TL. However, the process of translation should be defined, not as a sort of mechanical transferring from one language to another; instead as an understanding of two languages and cultures. As Levý (1963) in Art of Translation observes:

A translation is not a monistic composition, but an interpenetration and conglomerate of two structures. On the one hand, there are the semantic content and the formal contour of the original, on the other hand the entire system of aesthetic features bound up with the language of the translation. (Levý, cited in Bassnett-McGuire, 1980, pp. 5-6)

Therefore, translation is an act of evaluating and analyzing the source text and then creating a new text in another language. In addition, according to Bassnett-McGuire (1980, p. 2),

first, that the surface meaning of the two, i.e., the Source Language and Target Language will be approximately similar; and second, that the linguistic structures of the two need to be preserved.

Bassnett-McGuire's observation is a reflection of the idea that translation is a technical task. However, many other scholars believe that translation is more than an act of transferring meaning from one language into another; instead, the cultural aspects of each language should be considered in the process of transaltion.

Traditionally, transferring an author's meaning, translators should recognize the text style. When translators analyze the text style, they need examining linguistic and paralinguistic choices such as sentence structure, diction, and tone which are connected with meaning. Indeed, familiarity with these aspects of style makes it feasible for translators to have a better understanding of the text.

However, today, translators need something more than stylistic and linguistic knowledge. Translation is no longer a word for word substitution; instead, it is considered as a cultural product that aims at reproduction of meaning and communication. Different languages and cultures and the significance of communication in life have caused translation to be an influential factor in exchanging cultural differences. Therefore, it seems that the relationship between translation and culture is significant to consider.

In the current study, the significance of culture in translation is discussed and argued how considering culture can lead to creative translation. As the cultural traits of every area are different, translators not only should consider 
how to convey the ST meaning, but also try to represent the differences between cultures of SL and TL.

\section{Literature Review}

Traditionally, it has been assumed that translation is a lingual task and void of any cultural perspectives. This attitude can be traced through the following definitions.

Catford (1965) sees translation as the substitution of textual materials in one language for equivalent materials in another language. For him, equivalent textual materials are significant. But, his concern is ambiguous in terms of the kind of equivalence. Similarly, Savory (1968) observes that translation is an act of replacement. Furthermore, Brislin (1976, p. 1) considers translation as:

the general term referring to the transfer of thoughts and ideas from one language (source) to another (target), whether the languages are in written or oral form; whether the languages have established orthographies or do not have such standardization or whether one or both languages is based on signs, as with sign languages of the deaf.

Likewise, Pinhhuck (1977, p. 38) claims that "Translation is a process of finding a TL equivalent for an SL utterance". On the other side, for Gui (1995) translation is fundamentally a creative process. He claims that translation is not a matter of transforming a source text into a literal text. Gui (1995) observes that a good translator should have creativity, and the work of a translator is like that of a painter or writer. Also, Newmark (1981, p. 40) observes that "translation is how to replace a written message and statement in another language". In fact, Newmark refers to the translator's potential of creativity, which helps him to reproduce a message in another language.

Wilss (1995) also sees the significance of creativity in translation. He claims that "the most competent translators possess a malleable and creative mind," that belongs to the translator's "translation intelligence" $(1995$, p. 166). Wilss finds translation as a "re-creative linguistic activity. Translation is never a creation ex-nihilo, but the context-bound reproduction of a given text" (ibid). He goes on:

nevertheless, translation creativity as a manifestation of translator behavior does exist, and it is, as any type of creativity, a dynamic notion. The dynamic aspect of translation creativity reveals itself not in original text production, but in the skill to develop, in simultaneous confrontation with a source text and a target code, decoding and encoding strategies. (ibid)

Furthermore, Neubert (1997, p. 17) explains that creativity in translation can be derived from the source text:

A translation is not created from nothing; it is woven from a semantic patter taken from another text, but the threads-the TL [target language] linguistic forms, structures, syntactic sequences-are new.

For Neubert (1997, p. 19), the target language can play a significant role in producing a creative translation. He claims:

In the course of achieving something new, mediators [translators and interpreters] have to resort to novel ways of encoding an old message. They are forced to creativity because the means of the TL are not identical with those of the SL [source language]. To arrive at an adequate TL version, new resources have to be tapped. In these efforts, creativity plays a prominent role. Creative uses of the target language are the result of the various problem-solving strategies applied to any piece of SL text.

Moreover, Nida (1996) finds translation as a creative process with perceptions from different disciplines. In addition, Snell-Hornby (1995) suggests that language norms provide the translators with an unlimited source of creativity. The translator should use the language norms creatively.

The present study highlights the significance of creativity in translation and also indicates the importance of culture in producing a creative translation.

\section{Significance of Culture in Creative Translation}

Culture, according to Newmark $(1988$, p. 3), is "the way of life and its manifestations that are peculiar to a community that uses a particular language as its means of expression". For Newmark (1988, p. 7), Culture is a complex whole including art, customs, belief, knowledge and some other features and conditions obtained by inhabitants of society.

There are cultural limitations in transferring the source text into target text. Every community has its own culture accepted, respected and performed by its people. Thus, it makes the translator's task much more complicated since he/she not only should be faithful to the author, but also should consider the reader's cultural interests. Today, translation is becoming affected through various cultural norms in both source and target languages and 
the translator should select the norms having priority over other norms. According to Snell-Hornby (1995), culture considers all social aspects of our life. In addition, Goodenough (1964, p. 36) states: "As I see it, a society's culture consists of whatever it is one has to know or believe in order to operate in a manner acceptable to its members, and do so in any role that they accept for any one of themselves". Culture is what people learn from society and includes the end product of learning. According to Goodenough "culture is not material phenomenon; it does not consist of things, people, behavior, or emotions. It is rather an organization of these things. It is the forms of things that people have in mind, their models of perceiving and dealing with their circumstances.

This definition has two perspectives: (1) culture is knowledge for understanding society; (2) there is a close relationship between culture, behavior and phenomena. In addition, some other scholars have claimed that knowledge as well as material things belongs to culture (Koentjaraningrat, 1996; Hoijer, 1967). Thus, culture can play a significant role in formation of people's attitudes towards art, knowledge, translation, etc. In this regard, translation is no longer a mere linguistic and stylistic act.

Recently, the idea that translation copes with linguistic components has been challenged. Munday (2004, p. 216) observes that up until now translation has been widely considered the "conventional, progressively outdated, written text", but now translation should be considered in a wider domain, beyond the linguistic elements. Likewise, Kress $(2010$, p. 11) sees that although translation has traditionally been considered as transferring linguistic elements, meaning should be observed "as a whole and handled modally across the range of modes in different societies".

Today, scholars believe that texts are made up of different semiotic sources such as cultural, historical, and social modes. As Kress (2010, p. 79) observes, a mode is, "a socially shaped and culturally given semiotic resource for making meaning". Indeed, language is no longer an absolute factor; instead, it is a mode among other modes for creating meaning. (ibid)

Nowadays, translators should concern the creation of meaning in both source and target cultures. To illustrate this point, de Mooij (2010) gives the example that the black sheep signifies different meanings in different cultures. For instance, in Italy it is the symbol of independence, while in other cultures it refers to something outcast. According to de Mooij (2004, p. 196), the translator should consider the cultural impacts on people's understanding, communication and memory. The translator should concern "culture-specific aspects of both languages". Thus, she sees the translator as a mediator between two cultures and languages. As Hatim and Mason (1990, p. 236) observe "the translator takes on the role of mediator between different cultures, each of which has its own vision of reality, ideologies, myths, and so on". The significance of being a mediator is also considered via Katan (2004), who states that translators are not mere copiers of texts, but they play an active and creative role in the communication processes.

However, the question is raised: how impartial are translators towards their cultural roots? According to Hatim and Mason (1990, p. 224), "ideological nuances, cultural predispositions and so on in the source text have to be relayed untainted by the translator's own vision of reality". But, some scholars cast doubt over this idea. For example, Venuti (2004, p. 482) claims that "translation is readily seen as investing the foreign-language text with a domestic significance... The foreign text, then, is not so much communicated as inscribed with domestic intelligibilities and interests". Similarly, Kotabe and Helsen (2011, p. 123) believe that people tend to be affected via their own culture in cross-cultural communications. Furthermore, Zethsen (2010, p. 555) observes that "culture-bound words and concepts pose a major challenge even to the experienced translator" and that "the receivers of a text will always superimpose their own cultural layer on their interpretation".

It seems impossible to know that how individuals in various target cultures may respond to a text. However, another question can be raised: is translation affected by the source text culture? Working as a cultural expert, or mediator, the translator may understand that deviation from the source text is necessary for creating the right effect on the reader. Then, a cultural factor in one language can be replaced via another cultural factor in another language, or be quite erased (Pedersen, 2011). Ho (2004, p. 232) exemplifies the issue in an advertisement in which the kiwi fruit was called "Chinese gooseberry from New Zealand" since it was unknown to Chinese people. Indeed, translation is a cultural phenomenon that has been formed and transformed over time. According to Snell-Hornby (2006, p. 155), "the concept of translation proper has changed through the centuries". In addition, she considers that the new advances in the area of multimedia have led to new kinds of text. For her, intercultural communication is more important than language mediation (ibid.). Therefore, the translator has a highly significant role, and is responsible for the final product based on cultural communication.

Indeed, a qualified translator should do more than pure translation. According to Helmersen et al. (2008), the 
translator is becoming involved in different types of foreign language corporation such as intercultural mediation, web communication and consulting. Therefore, there is no longer a distinct border between a translator and a language expert. Regarding the various conceptualizations of "texts" and "translations", the present study consents with Kress (2010, p. 103) who observes the creation of "new entities, new relations, new processes need new names" in translation.

Kress (2010, p. 124) considers the changing nature of meaning between semiotic divisions, and within a culture or between cultures. He believes that the term translation traditionally has pointed to inter-lingual exchanges. Thus, Kress sees translation as a hyperonym that is "process of drawing/'dragging' meaning across from one mode to another" and transformation as hyponyms that refers to the traditional meaning of translation that is to translate a print text from one language to another. Thus, the term translation is known with new traits.

\section{Conclusion}

As we discussed, translation has been typically seen as an act of creation and reproduction rather than replacement of the SL with some equivalents in the TL. In the following, some of these reasons are counted:

- Translation is not just the transformation from one language to another, but should meaningfully transfer the overall messages of the original text, involving the cultural, social, and historical significance, in a sense familiar and meaningful to the TL and culture. Indeed, the translator is like a messenger that must understand the message fully and transfer it to the TL in way that seems appealing to the reader. Thus, the translator should know about cultural features of both the SL and TL.

- Translational creativity escapes absolute definition.

- Translators should possess a creative and flexible mind. Thus, translation is a manifestation of translator's creative and dynamic mind.

Generally, creativity is in the essence of translation. In fact, without creativity the translatability of a text is difficult to achieve. In other words, it is creativity that makes a text translatable into another language.

Consequently, it can be said that stylistic and linguistic aspects of both SL and TL must be considered in translation but they are not enough to achieve creative translation. In fact, creation is integral to the work of translation, which is always an act of extension, beginning from a ST and moving to a new place.

\section{References}

Bassnet-McGuire, S. (1980). Translation studies. London: Methuen.

Brislin, R. W. (1976). Translation: Application and Research. New York: Gardner Press Inc.

Catford, J. C. (1965). A Linguistic Theory of Translation. London: Oxford University Press.

De Mooij, M. (2004). Translating Advertising. Painting the Tip of an Iceberg. The Translator, 10(2), 179-198.

De Mooij, M. (2010). Global Marketing and Advertising: Understanding Cultural Paradoxes. Thousand Oaks: Sage Publications.

Goodenough, W. H. (1964). Cultural Anthropology and Linguistics. In D. Hymes (Ed.), Language in Culture and Society. A Reader in Linguistics and Anthropology. New York: Harper \& Row.

Gui, G. (1995). Das Wesen des Übersetzens ist kreativ. Babel, 41(3), 129-139.

Hatim, B., \& Mason, I. (1990). Discourse and the Translator. Harlow: Longman.

Helmersen, O., Lauridsen, K., \& Norlyk, B. (2008). New Trends in the Language Profession: A Report from the World of Work. LSP and Professional Communication, 8(1), 8-22.

Ho, G. (2004). Translating Advertisements across Heterogeneous Cultures. The Translator, 10(2), 222-243.

Katan, D. (2004). Translating Cultures: An Introduction for Translators, Interpreters and Mediators. Manchester: St. Jerome Publishing.

Kotabe, M., \& Helsen, K. (2011). Global Marketing Management. Hoboken, NJ: John Wiley and Sons, Inc.

Kress, G. (2010). Multimodality: A social semiotic approach to contemporary communication. London and New York: Routledge.

Levý, J. (1963). Umění překladu [The art of translation]. Prague: Československy Spisovatel.

Munday, J. (2004). Advertising: Some Challenges to Translation Theory. The Translator, 10(2), 199-219.

Neubert, A. (1997). Postulates for a Theory of Translation. In J. Danks et al. (Eds.), Cognitive Processes in 
Translation and Interpreting (pp. 1-24). Thousand Oaks: Sage.

Newmark, P. (1981). Approaches to Translation. Oxford: Pergamon Press.

Newmark, P. (1988). A Textbook of Translation. New York: Prentice Hall.

Nida, E. A. (1996). Translation: Possible and Impossible. Translation Horizons beyond the Boundaries of Translation Spectrum. Binghamton: Suny.

Pedersen, J. (2011). Subtitling Norms for Television: An Exploration Focusing on Extralinguistic Cultural References. Amsterdam/Philadelphia: John Benjamins.

Pinchuck, I. (1977). Scientific and Technical Translation. Andre Deutsch.

Savory, T. (1969). The Art of Translation. London: Jonathan Cape Ltd.

Snell-Hornby, M. (2nd ed.). (1995). Translation Studies: An Integrated Approach. Amsterdam: John Benjamins.

Snell-Hornby, M. (2006). Turns of Translation Studies: New Paradigms or Shifting Viewpoints? Amsterdam/Philadelphia: John Benjamins.

Venuti, L. (2004). Translation, Community, Utopia. In L. Venuti (Ed.), The Translation Studies Reader. London and New York: Routledge.

Wilss, W. (1996). Knowledge and Skills in Translational Behavior. Amsterdam/Philadelphia: John Benjamin Publishing Company.

Zethsen, K. K. (2010). Has Globalisation Unburdened the Translator? Meta: The Translators' Journal, 55(3), 545-557.

\section{Copyrights}

Copyright for this article is retained by the author(s), with first publication rights granted to the journal.

This is an open-access article distributed under the terms and conditions of the Creative Commons Attribution license (http://creativecommons.org/licenses/by/3.0/). 